\title{
日本表面真空学会 \\ Professor Charles S. Fadley 追悼記事
}

大門 寛（豊田理化学研究所フェロー）

本学会の初の国際フェローであり, 光電子回折の創始者として名高く, 世界の放射光表面 光電子分光のリーダーとして長年活躍されてきた Charles S. Fadley 教授（愛称 Chuck）が，本 年 2019 年 8 月 1 日未明（現地時間）に数年に及ぶ癌との闘病の末, 享年 77 歳で永眠されま した。皆様と共に心から哀悼の意を表したいと思います。

Chuck は 1941 年 9 月に米国オ八イオ州で生まれ，大学はマサチューセッッ工科大学を 1963 年に卒業し, 大学院はカリフォルニア大学バークレー校に入り, 博士課程でD.A. Shirley 教授 の下でXPS による価電子と内殼の電子状態の研究をして 1970 年に卒業しました。その後, ポスドクなどを経て, 1974 年からハワイ大学の化学科で准教授, 1978 年から 1991 年まで教 授を務めました。1990年にバークレーにできた世界最初の第三世代放射光施設 ALS (Advanced Light Source) に移り，カリフォルニア大学デービス校の物理学科とローレンスバ ークレー国立研究所の教授を最後まで兼務していました。

ハワイ大学では，角度分解 XPS の装置を立ち上げ，河野省三教授やチューリヒ大学の Juerg Osterwalder 教授などが若い頃に滞在して, 光電子回折の分野はここから世界に広がっていっ たと言えます。1970 年代の後半には Stanford の放射光施設を使って放射光光電子回折の実験 を進めていました。ALS に移動した 1990 年頃から光電子ホログラフィーの研究を行っていま す。その後は, スピン, 磁性, 共鳴光電子, 2000 年くらいからは定在波の研究を, 2009 年く らいから硬 X 線光電子分光（HAXPES）を始めるなど, 常に放射光表面光電子分光の先端を 走っていました。HAXPES では SPring-8にも来て実験をしていました。Chuck は，生涯 235 件にも上る招待講演でこれらの研究を世界中に広め, 多くの研究者を常に敬蒙してくれてい ました。論文の数は 332 に上り，平均引用数は 36 と高いレベルを保っています。

科学コミュニティへの貢献としては, 電子分光国際会議 ICES（International Conference on Electron Spectroscopy, 第 8 回目から Chuck の発案で ICESS : International Conference on Electronic Spectroscopy and Structure に変更）では組織委員会のリーダーとして活躍しました。 その他, VUV（後にVUVX）やHAXPESの常連の組織委員でした。日本関係では, 本学会の 国際会議 ISSS や学振 141 委員会の ALC の国際顧問をしてくれていました。私が代表をして いた新学術研究「3D 活性サイト」でも国際アドバイザを引き受けてくれて, 2016 年の 7 月 にチューリヒ大学でVUVXのサテライト会議を開催したときにも来てくれました。受賞も数 多く, Helmholtz-Humboldt Award, 2006-2007, AVS Welch Award 2005 などの他, 日本の関係 では前述した本学会初の国際フェロー, 学振 141 委員会ではJSPS 141 Award 受賞するとと もに国際名誉会員になっています。奥さんのSusan さんが日系二世だったこともあり，日本 人には特に親近感を持って接してくれていたと思います。

私がバークレーの Chuck の研究室に滞在したのは 1994 年 7 月から 1995 年 5 月までの 10 ケ 月です。Chuckの ALS の装置は, Scienta アナライザーが大きなベローズで回転するようにな 
っている大掛かりなもので，支柱が青いの でBig Blue という相性で呼ばれていました。 Big Blue とご満悦の Chuck の写真を Fig. 1 に示します。私はこの装置で円 2 色性の光 電子回折の実験をしてきました。

ALS もChuck の自宅もサンフランシスコ 湾を見下ろす丘の中腹にあるため, 夕方に はゴールデンゲートブリッジに夕日が沈む という絶景に恵まれた素晴らしい場所でし た。2016 年の 9 月にバークレーで 75 歳の 誕生パーティーを開き，世界中から関係者 が集まってお祝いをしましたが，その頃は 既に治療の最中だったようです。2018 年 9 月に TASPEC (Trends in Advanced Spectroscopy in Materials Science) という会議に 招待して，来てくれることを楽しみにして いましたが，来られないという連絡があり， 皆さんどうしたのだろうと心配していた所 でした。あらゆる治療法は試みたそうです が甲斐なく，残念でした。あんなに元気で

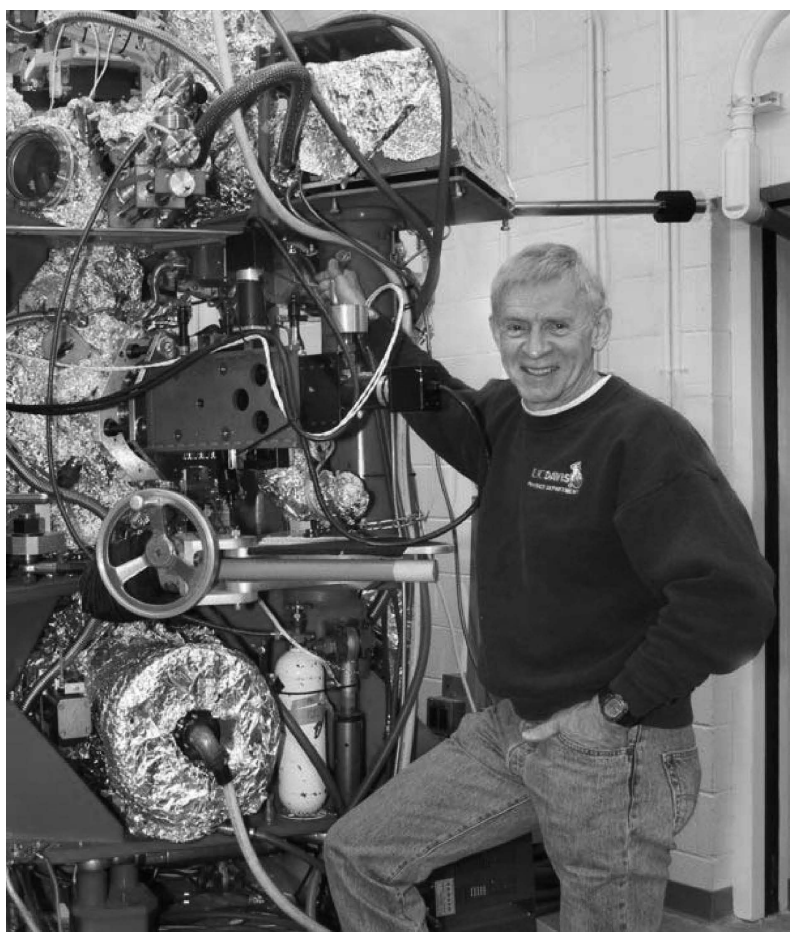

Fig. 1. (color online). Chuck と Big Blue (LBNL の追悼 記事 https://als.lbl.gov/in-memoriam-charles-fadley-pioneerin-x-ray-photoelectron-spectroscopy/より。) 活動的だった Chuck が亡くなるなんで信じ られませんが，これまでの長年に渡る学問上と学会への貢献を讃え，世界中，特に日本の多 くの研究者への支援に感謝して，皆様と共に心からご冥福をお祈りしたいと思います。 